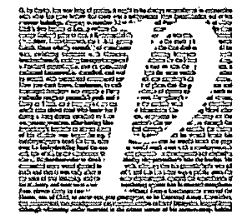

\title{
Portia as Primavera: Cultural Memory in The Death of the Heart
}

Wendy B. Faris

The University of Texas at Arlington

$\mathrm{N}$ ear the end of the second part of Elizabeth Bowen's novel The Death of the Heart, the cad Eddie calls the ingenue Portia "Primavera." I wish to argue that in this moment Bowen appropriates Botticelli's painting, Primavera, as a subtext for her novel and with it the grace and charm of Renaissance Italy. The appropriation achieves a spring thaw in the cold atmosphere of upper middle class London (both metaphorically and literally wintry), a renaissance of elegance in a vulgar seaside villa, and an implied critique of that coldness and vulgarity. In speaking of her ancestral home at Bowen's Court, Bowen claims that "the house stamps its own character on all ways of living. I am ruled by a continuity that I cannot see" $(1942,449)$. The virtual presence of Botticelli's Primavera, or, if not the painting, the Renaissance mythological portrait its name suggests, is perhaps one of the continuities that rule Bowen's text, seen or unseen by her.

Botticelli's painting is so well-known that Bowen is likely to have been familiar with it, although I have found no concrete evidence that she had it in mind as she wrote Portia's story. That Bowen may have accepted the help of painted portraits in creating

Poligrafias IV (2003) 179-194

(C) Poligrafias. Revista de Literatura Comparada. División de Estudios de Posgrado, Facultad de Filosofia y Letras, Universidad Nacional Autónoma de México, Ciudad Universitaria, México 04510 DF. Tel. (525) 622 1835(6). Fax (525) $6221801 ; 6160047 ; 6221826$. 
her own verbal ones is suggested by her comment that "I find I visualize the people I'm writing about in the same terms, with the same blanks and qualifications, as I remember people who have impressed me but that I cannot always see in entirety. I can see all Henrietta [from The House in Paris] except her features; Karen's figure, movements and ways but I don't know what kind of nose she had." Botticelli's Primavera may have helped Bowen to fill in the blanks, as it were, in Portia's portrait. In any case, even if my arguments for Botticelli's influence are not definitive, it is useful to explore the affinities between Bowen's text and Botticelli's painting. Most centrally, the very name, Primavera, alerts us to the importance of seasonal change and its juxtaposition with allegorical meaning in Bowen's novel, and enriches our understanding of its structure, its characterizations, its social satire, and its cultural depth.

To summarize briefly, Bowen's use of Botticelli's painting provides her with the means for a double critique of the springtime Portia experiences in England. On the one hand, Portia as the delicate European Primavera exposes "the upright rudeness of the primitive state" she finds at the vulgar English seaside villa, "Waikiki," whose inhabitants with their relentlessly modern amusements exhibit "behavior that was pushing and frank," although she finds that very frankness refreshing in contrast to the frigid upper class drawing room at Windsor Terrace in London $(1962,171$; further citations will be given with page numbers in the text). The modernity of both those houses is juxtaposed with Eddie's desire that Portia "must never show any sign of change" and contrasts with the graceful portrayal of change in the Botticelli painting, change which, as we shall see in a moment, is subject to timeless values (212). On the other hand, the appropriation of the Primavera is not without its attendant problems; to focalize Botticelli's gaze through Eddie's eyes is to rehearse implicitly several centuries of the male gaze, and thus to suggest the continuity of bodily appropriations that join Renaissance Italy to twentieth century England. Eddie the would-be novelist and Botticelli the masterful painter both virtually denude their models and cover them with flowers.

That Bowen is likely to adopt a Renaissance painting as a foil for modernity is confirmed by her fondness for her ancestral home, Bowen's Court, of which she says, "there is no house like Bowen's Court, with its great pale Renaissance plainness set under near mountains among showering trees," and the way in which she compares its surroundings to modern England: "That air of waste and nonchalance about Irish ruins is an irritant to the present day English mind. But when fancy loomed larger than economics, when fine degrees of melancholy were sought, travellers turned on our ruins a much more complaisant eye" $(1942,108,116){ }^{2}$ More specifically, in a letter to Lady Ottoline Morrell, Bowen describes a marriage in terms that recall the mode of Botticelli's Primavera, itself thought to have been painted for the occasion of Lorenzo di Pierfrancesco's wedding to Semiramide: "David's wedding was just as it should be -graceful, formal, romantic, utterly unsentimental. Cynthia Asquith said 'Like the marriage of a pair of royal children' -and it was. Like a little Valois marrying a still younger Velasquez (sic) princess. And both looked transparent and serious, like a pair of children." 3 The transparent, graceful, serious, and fresh quality that Bowen admires in this young couple is what Portia as Primavera represents, in contrast to the world 
around her. In contrast to the other Renaissance text evoked specifically in the novel, the "Elizabethan play," in which children are led on and off, "bound for some tragic fate which will be told in a line," this visual one allows Portia more scope, but pictures it within a graceful paradigm (297-98). ${ }^{4}$

A major way in which this visual subtext from another era illuminates Bowen's novel can be found in the neoplatonic philosophy contemporaneous with the painting. A neoplatonic interpretation of Botticelli's painting reveals that its movement is orchestrated from right to left, following the impetus of Zephyr's breath, and that this movement corresponds to the soul's progress from the birth and blossoming of physical desire in the first two female figures to the right, through its fulfillment on earth in the figure of Venus as Harmony at the center, and its final transformation through the generous love of the three graces to the left, into the intellectual and contemplative plane indicated by the figure of Mercury pointing upward (see figure 1$)^{5}$

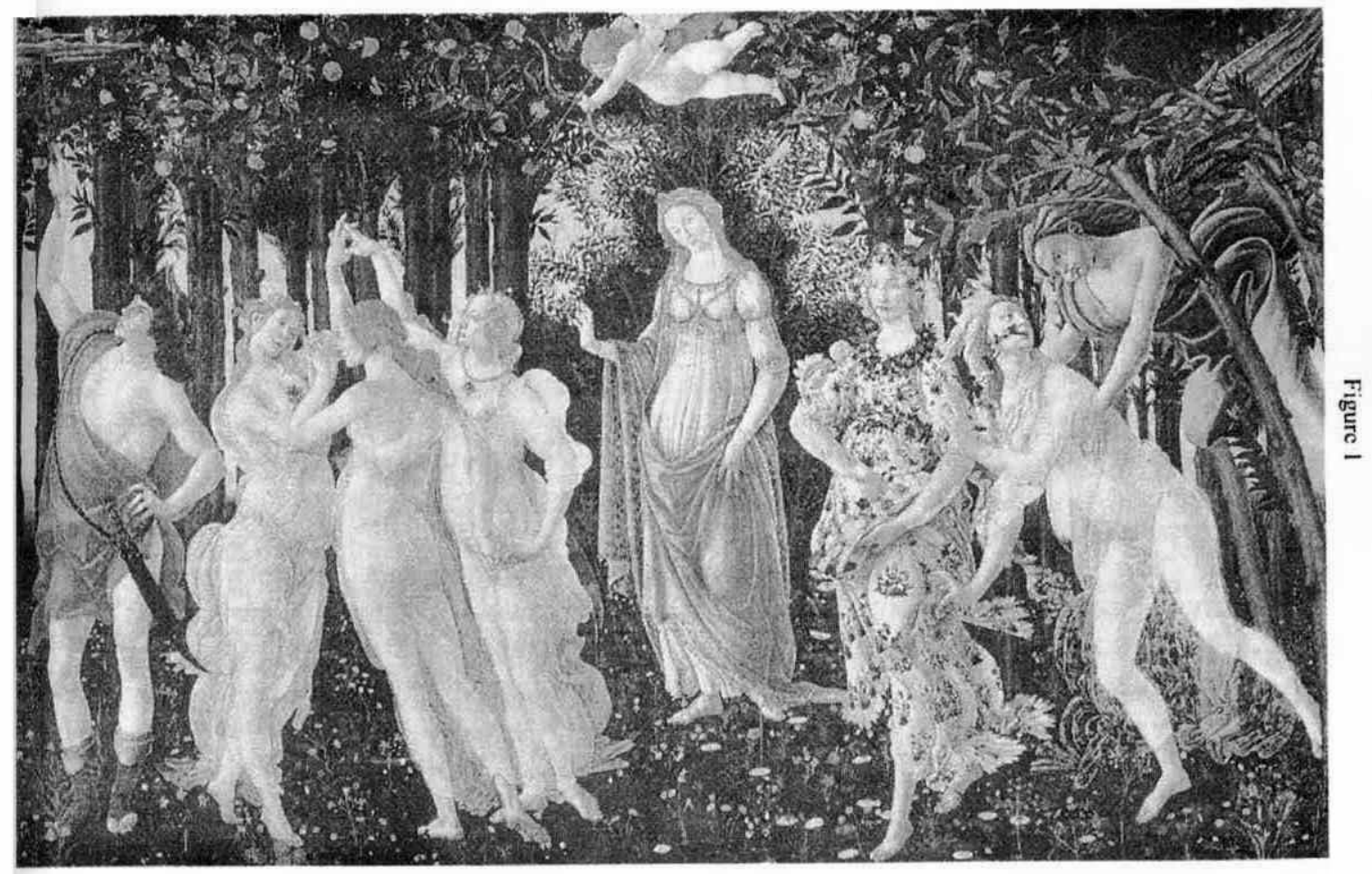

A relate 1 neoplatonic echo is that in painting Portia as Primavera, Bowen subliminally duplicates Ficino's doctrine that the direct vision of virtue was more effective than verbal arguments. This is the effect that viewing Portia as Primavera and reading her diary with its direct portraits of her adopted family has on the jaded social world that she enters. She and her text are direct visions of virtue rather than abstract arguments in its favor. The subtle clarity of the Renaissance allegorical visual style pro- 
vides a critique of the modernist verbal cleverness that St. Quentin and Eddie represent. Talking with Portia, St. Quentin says about his own novels that "what's in them never happened - It might have, but never did. And though what is felt in them is just possible -in fact, it's much more possible, in an unnerving way, than most people will admit- it's fairly improbable" (249).

Even leaving aside the neoplatonic philosophical context, Botticelli's painting is especially appropriate for this story of the progress of a young girl because it presents the progressive coming of spring. Furthermore, while the entire painting evokes a general sense of springtime temporal progression and harmony rather than narrating a particular mythological narrative, the one mythological story Botticelli does include corresponds to Portia's age. This is the transformation of Chloris into Flora following Zephyr's pursuit of her, which is depicted in the female figures to the right, Chloris having only a few flowers springing from her mouth, and Flora, on the other hand, fully flowering. The place of the right kind of love in this process of transformation is implied in the neoplatonic interpretation of the painting, which provides a philosophical backdrop for Eddie's inadequacies as a suitably platonic and generative lover.

In the Primavera taken as a whole, Zephyr's breath personifies time, which flows through the painting from right to left, drawing leaves and flowers from early to full spring, and then through summer to autumn. Similarly, Bowen charts the passage of time with seasonal descriptions at the beginning of each of the novel's parts, and additional references throughout, which chart the progress of spring in London. But that progress, like Portia's development, is awkward and interrupted, the modern appropriation of the Renaissance necessarily incomplete. At the level of cultural archeology, besides representing a longing for Renaissance grace and neoplatonic ideals, perhaps this nearly secret analogy between Portia and Primavera encloses a nostalgia for the complex web of resemblances that Foucault characterizes as the Renaissance episteme and which, once again, contrasts with the emotional and physical dislocations of modernity (Foucault 1973, 17-34).

That in addition to symbolizing spring, the Primavera is also sometimes seen as representing Florence, enriches Bowen's critique of a sector of London society. Anna's small circle of mediocre artists is a clique not a court, and if its surroundings may be beginning to flower physically, they, unlike Lorenzo's court, which was flourishing with new and fruitful ideas at the time of Botticelli's painting, are not flourishing intellectually, artistically, or emotionally. Thus, broadening our focus, we can consider the Primavera as representing not only the passage of the seasons but also as the evocation of an ideal society. It would then picture the reign of Venus-Humanitas (hardly Anna's mythological portrait), or civilization, which through neoplatonic doctrine is joined to a heavenly realm. ${ }^{6}$ This ideal does not exist for Portia in London, where her main intellectual pursuits -at the socially pretentious but artistically and intellectually uninspiring Miss Paullie's school- are undertaken underground, the polar opposite of the heavenly realm signaled by Mercury in Botticelli's painting.

Botticelli's Chloris, with her sprig of foliage representing early spring, corresponds to Portia just after she arrives at Anna's house wearing her mourning black, and Anna, 
blowing on her, immediately outfits her in colors. The novel's initial scene begins before that point, however, because Anna's reading of Portia's diary, which inaugurates Portia's irruption into Anna's frigid social world, takes a while to have an effect. Although in the first paragraph of the novel (at the start of the part entitled "The World"), the "morning's ice, no more than a brittle film, had cracked and was now floating in segments," as if in anticipation of Portia's shattering of Anna's emotionally frozen world, by the end of the paragraph which describes the "bronze cold of January," whose "sky was shut to the sun," we hear that "it would freeze harder tonight." Spring's arrival, while foreshadowed, has not really begun to occur.

The beginning of Part 2, "The Flesh," forms a seasonal contrast, and a direct analogue to Portia's arrival at the Quaynes' house. It is early March when "the crocuses crept alight, then blazed yellow and purple in the park." The bright colors suggest Portia's irrepressibly critical spirit, but after that initial flash of color, Bowen continues her painterly description with more attention to the quality of light. She paints the coming of spring with an attention to seasonal movement and delicately described detail that are analogous to Botticelli's carefully orchestrated seasonal observation expressed in finely painted leaves and flowers:

it is about five o'clock in an evening that the first hour of spring strikes .... The air, about to darken, quickens and is run through with mysterious white light; the curtain of darkness is suspended, as though for some unprecedented event. There is perhaps no sunset, the trees are not yet budding -but the senses receive an intimation, an intimation so fine, yet striking in so directly, that this appears a movement in one's own spirit. This exalts whatever feeling is in the heart. (123)

By now the reader hopes that this springtime exaltation may reach even Anna. The references to a "mysterious" white light, to a movement of the spirit, and to exaltation, correspond to the neoplatonic echoes in the Primavera. And as if to recall Botticelli's painting explicitly, Bowen personifies spring and refers to the two phases represented by Flora and Chloris that the painting records: "The later phases of spring, when her foot is in at the door, are met with a conventional gaiety. But her first unavowed presence is disconcerting" (123). The parallel to Portia's disconcerting arrival is clear.

In addition to this temporal similarity, there are structural parallels as well, which further confirm the deep affinity between The Death of the Heart and Primavera. As in Botticelli's painting, in which the central space is divided between the more mature figure of Venus and the lighter colored and yet more enchanting figure of Flora, Bowen's novel is divided in its central focalizations between Anna and Portia. Apparently, Flora enjoyed more popularity in Florence as a symbol of spring than did Venus, also a spring goddess. Just as in the painting in which Venus's central role is usurped by the enchanting and youthful beauty of the emerging figure of Flora to her right (see figure 2), Anna's central place in her world is being invaded by the increasingly more popular Portia. Not only Anna's intimate friend Eddie, but even Anna's husband Thomas seems drawn to the emotional warmth of his half sister. And, as in the case of Flora, Portia is all the more appealing because she is not overtly seeking the center of the stage (Anna says that "everything she does to me is unconscious; if it were con- 
scious it would not hurt"), and yet she seems impelled toward it by cosmic forces -like the invisible but motivating breath of Zephyr in the Primavera.

The final seasonal piece, at the start of

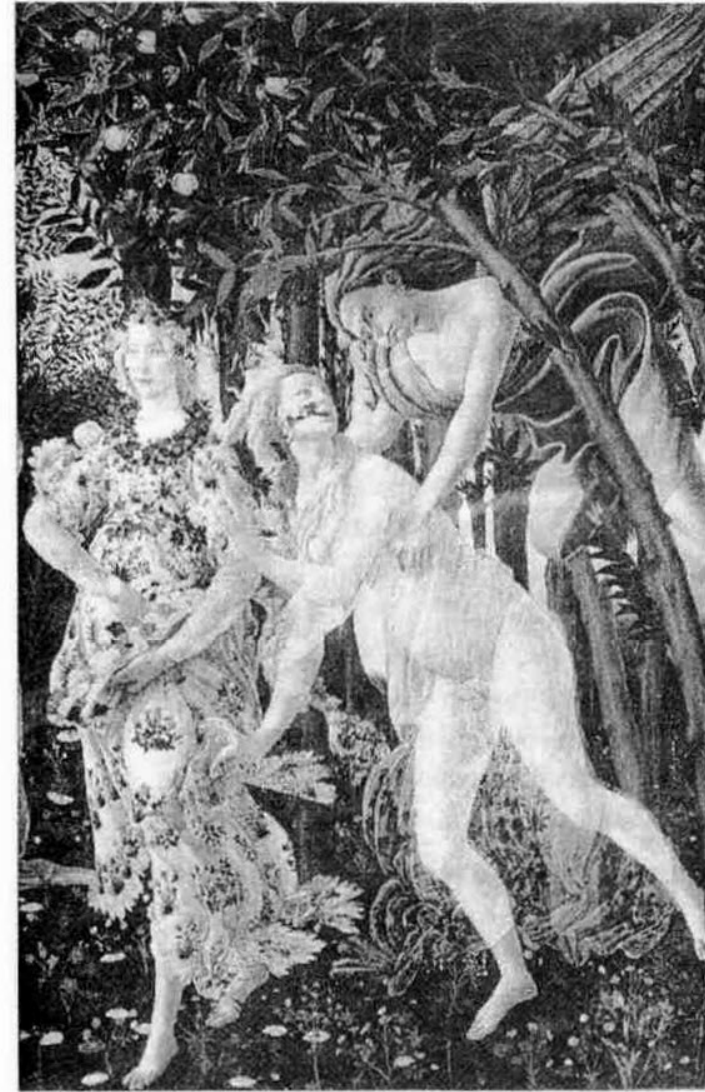

Figure 2 Part III, "The Devil," describes the Quaynes' house in London after its spring cleaning. It is April, and while outside the chestnuts are in leaf, continuing the foliage theme, from the inside everything is surface and glare. Matchett's housecleaning, rather the opposite of Matchett herself in the novel's emotional economy, rids the house of its immediate past, leaving it "in immaculate emptiness," offering "that ideal mould for living into which life so seldom pours itself" (229). The almost unearthly "blue spirit had removed the winter film from the mirrors; now their jet-sharp reflections hurt the eye; they seemed to contain reality. The veneers of cabinets blazed with chestnut light." Matchett's artistry in cleaning thus contrasts with Botticelli's representation of temporal flow by virtually erasing its traces. Matchett herself, on the other hand, is an embodiment of temporal continuity; a holdover from the old regime of Thomas's mother, she is immensely comforting to Portia for her old-fashioned virtues of continuity, duty, emotional honesty, and tact. While we are not really glad of the pollution, it is almost with a sense of relief that we see the renewal of temporal flow-time may equal grime, but it is preferable to the harsh glare of a ruthless present reality in which the house "was lanced through with dazzling spokes of sun, which moved unseen, hotly, over the waxed floors": "Crisp from the laundry, the inner net curtains stirred over windows reluctantly left open to let in the April air with its faint surcharge of soot. Yes, already, with every breath that passed through the house, pollution was beginning" (229).

Even though spring has begun at the start of Part II, Portia must wait for Eddie and their encounters at the warmer seaside to transform her into Primavera proper. As they sit under an old oak tree, he tells her "these violets [which she has fastened in his buttonhole] ought to be in your hair -oh, Primavera, Primavera, why do they make you wear the beastly reefer coat?" (216). In case we should miss the reference, he repeats the name twice, capitalized. The "beastly reefer coat" seems made to contrast specifi- 
cally with Primavera's portrait by Botticelli in a diaphanously revealing dress. Haying spent much of her life in Europe, Portia as Primavera is out of place in this modern English world. And the comparison of Portia to this superb painting marks her as special in some barely definable way, and delicate, like the figures of Chloris and Flora and in the Prinavera. A bit later, as they come home on the bus, as if to transform her back out of her nythological incarnation, and to confim its allegorical significance in our eyes, he "pulled shreds of moss and a few iridescent bud scales from Portia's hair" (217). Even back on the bus, Portia retains some of the magic of her embodiment as Primavera in the iridescence of the bud scales that cling to her hair. Portia and Eddie use Eddie's comb to make themselves more presentable for the social world they are about to reenter, but, still attached to the more natural setting of her suythological self, Portia sticks her head out of the bus window, and has to borrow the comb again to rearrange ber hair.

The setting of this scene corresponds to its painted subtext as well. Foliage and fiowers are much present, as in the Botticelli, and as there, they not only create a delicate backdrop for the figures, but are interwoven with them, forming an integral part of the whole: "Scales from buds got caught on Portia's hair. Small primroses, still buttoned into the earth, looked up from ruches of veiny leaves -and in sum-blond spaces at the foot of the oaks, dog violets bumed their blue on air no one lad breathed" (210). As in Botticelli's painting, the flowers are allegorized and active. And Portia as the human embodiment of the force that moves them is imbricated in their field: "Portia looked at the sky through the branches over their heads," and is "unlacing twigs in front of her face." Displaying for us the advancing spring, "the sun, striking down the slope of trees, glitterzd over the film of green-white buds" $(211,217)$.

This outdoor setting contrasts with the interiors where nost of the action transpires. Such a realm, which can be seen to embody natural emotion, is tare, and Portia and Eddie have to go through "vigilant notices that said Private" to reach it (210). It contrasts with the relentlessiy decorated atmosphere of Waikiki with its "highly jelled, sweet, and brilliant orange" marmalade, iks fake Chitese breakfast china, and synthetic oak table, which Bowen clearly satirizes but which she also has Portia's untutored eye and emotionally starved heart think pleasant both because its emotional freedom contrasts with Amna's repressive decor and because it recalls the emotional warmth of the unfashionable hotels she shared with her mother. Portia experiences this interlude at the seaside, then, despite its tasteless decor, as a welcome retreat to a primitive state, in which actions represent emotions with something like the mimetic immediacy that foucault assigns to Renaissance culture (althongh of course without its engaging style). Thus in sonte sense Bowen's equivalent of the neoplatonic ideal is the realm of genuine feeling which contrasts with its pale and degraded reflection below. 1 is the emotional wamth we can only imagine between Irene and Portia. In Foucault's archeological tems, Portia's and Anna's different emotional worlds constitute different conditions of possibility for the construction of lives.

To return to the bucolic scene where Eddie paints/names Portia, he is the intruder in nature, the portraitist that sees the setting but is not of it as his model is, A failed novel- 
ist, Eddie's fate is forever one of secondariness, cadging dinners at Anna's house, accepting a job she gets for him at Thomas's firm. With his virtual painting of Portia, he indirectly and inadvertently creates the masterpiece his fiction has failed to achieve -a precociously postmodern pastiche fitting Portia to her prepainted portrait. Eddie is able to evoke but neither to embody (or to create) a Botticelli. He must make Portia perform that for him.

In this central scene, Portia's connection to the earth is direct and emotional, his secondary and entrepreneurial. "Her knees received from the earth a sort of chilly trembling," in tune with the emotions of rejection and wretched attachment she is feeling. Eddie, on the other hand, burns the moss with his cigarette, and Portia laments the damage. Earlier, a paragraph suggests their relative relations to the mutability and truth of the natural world:

Rolling away from her, Eddie huntedly got to his feet and began to go round the thicket: she heard the tips of the hazels whipping against his coat. He paused at the mouth of every tunnel, as though each were a shut door, to stand grinding his heels into the soundless moss. Portia, lying in her form in the grass, looked at the crushed place where he had lain by her -then, turning her head the other way, detected two or three violets, which, reaching out, she picked. She held them over her head and looked at the light through them. Watching her from his distance, spying upon the movement, he said: "Why do you pick those? To comfort yourself?" (213-14)

The paragraph is divided between them, indicating their distance from each other and their different imbrications in nature. Eddie feels threatened or cowardly predatory there, either hunted or spying. The hazel tips whip his coat, as if to confirm that he doesn't belong, and he experiences this labyrinthine thicket not as a bower of bliss but a series of dead ends, and as if in response to its inhospitability, vengefully grinds his heels into the defenseless moss.

In direct contrast to Eddie's grinding of the moss, Portia's form is molded into the grass; she notices the damage that he has wrought, and turns away from it to appreciate what nature has to offer at this time of the year. The harmonic relationship between Portia as Primavera and nature, in contrast to Eddie's status as grass-crushing intruder, is exemplified by the maidens in Botticelli's painting, who, as Ugo Foscolo describes them in his contemporaneous poem, "Le Grazie," "do not bend the grasses as they dance." Near the beginning of this part, Bowen tells us that the senses of "very young people" are "tuned to the earth, like the senses of animals" (124). Portia, as usual, while intuitively responsive to the quality of the light, which indicates her sensitivity to the passage of natural time and emotional temperature, is less developed in analysis, and so has no idea why she has picked the violets. "Portia was not like Anna, already half way through a woman's checked, puzzled life, a life to which the intelligence only gives a further distorted pattern" (124). The reader, however, contemplating her as Primavera, senses that her action is part of her nature as spring. And Eddie, who, if not able to live his life fully and connected to its natural processes, can sometimes analyze it cleverly, here intuits correctly that Portia's action is an attempt at comforting herself. While he can analyze Portia's use of them, Eddie is alienated from the actual violets, 
calling them "wretched," until he can again perform the artistic arranger's role: "Why pick them for nothing? [as if emotional comfort were "nothing"] You'd better put them in my buttonhole." In executing his work of art, she fumbles with the stalks of the flowers, now herself alienated from her natural realm.

Like Eddie, who is farther advanced in age then Portia, the only fully embodied male figure in Botticelli's painting is Mercury, who represents the future red of autumn, ahead of the maidens of spring and summer. But there the analogy ends and the critique begins, for in a neoplatonic interpretation of the painting, Botticelli's Mercury not only represents a more advanced season, but a more advanced moral state of mind, his right hand with its wand directing the sensual movement of the painting upward to the spiritual realm, as Eddie does not. Thus, as I have suggested above, once again Botticelli serves Bowen as an implicit moral critique of her times and its manners.

In the gallery of interartistic lovers, by comparing his companion to a Botticelli painting, Eddie resembles an English Charles Swann, who uses Botticelli's Zipporah as the means to translate the common Odette into an aesthetically respectable object of affection. ${ }^{8}$ The characters and their intentions are of course vastly different: the vulgar, duplicitous, and scheming Eddie is in many ways the polar opposite of the urbane, scholarly, and generous Swann in love. And Swann bears the brunt of his (albeit narcissistically organized) suffering himself; Eddie manages to shift much of the burden onto Portia. It is she rather than he whom we see transforming from awkward duckling to swan-like beauty in her suffering. Thus Bowen has reversed the sexes in one sense, giving Portia the refined sensibility and Eddie the vulgar. But not in another, for Eddie's exclamation summarizes several centuries of male gazing in which even adoration immobilizes its object. However, in this case, the immobilizing gaze is countered by the mutability of Botticelli's painting and Portia's embodiment of that natural movement (to say nothing of her writing), which challenges Eddie's static desires. Bowen answers James's portrait of a lady who is ultimately immobilized by her admirer's mania for collecting beautiful objects by painting this portrait of a young girl who may ultimately write her way out of that fate.

To pursue the Proustian connection a bit farther is to understand more about Bowen's critique of the gaze. According to Mieke Bal, in her study of Proust, Marcel is a voyeuristic subject, who "sees without being seen, and whose gaze is charged with eroticism." This voyeurism is an "attempt to know the other," a knowledge which is both deeply desired and admitted to be inaccessible. Thus Marcel is involved in an "ethnographic" voyeurism, and his gaze involves "how to study the other, that is, those other people whom one wants to know, having realized the radical otherness that separates them from the I" $(1997,93)$. Eddie, on the other hand, seems not to have reached even this minimal level of differentiation. He uses Portia in constructing his fragile self by attempting to make her into a mirror, but in a sense, he has not yet arrived at Lacan's mirror stage because he does not recognize the mirror as separate from himself, so that he cannot differentiate Portia from the needs he has projected onto her. He tells her, for example, that if she ever stops liking him not to let him see it, because "for Eddie, Portia's love seemed to refute the accusations that had been brought against him for 
years, and the accusations he had brought against himself," accusations which he seems to fear her diary may induce in her, and so he wants her not to write about him in it (107). In attempting to use her in this way, he denies her mind its natural process of self-awareness and growth, telling her later on, "you must never show any sign of change" (212). Returning to the neoplatonic subtext for a moment, if "Mercury, in his Orphic role as conductor of the dead, indicates to Love, who has risen from passion to the ecstasy of contemplation, the infinite horizons of the world beyond, which transcends both speech and reason," it is clear that Eddie, whether we consider him either in relation to Anna or to Portia, unlike Botticelli's neoplatonic Mercury, subverts rather than enhances the platonic ascension of the developing soul (Bal 1997, 90).

Although Eddie is wrong to wish her never to change, Portia functions within the novel both as everchanging and neverchanging - like a stationary painting that figures the passage of time. This is her peculiar charm: she has the innocence of youth and its eternal wisdom as well. That combination is embodied in the Primavera's synthesis of mutability and order, which is achieved through the several movements from right to left in combination with the balanced composition of the painting. Similarly, Primavera herself, although fully formed in the timeless allegorical mode of the portrait, is situated to the right, and, like Portia, moving toward the center of the text. On the one hand, as Portia exists in time, the forces of nature pull her forward, as Botticelli's pictorial narrative does Primavera. This is the novel's principal temporal mode, and it is why Botticelli's painting is a guiding subtext. However, there is a side to Portia that stays largely the same. Her soul remains a spring soul, and we readers hope it will always retain that aura. From the temporally developmental point of view, her invitation to Major Brutt to marry her is simply the desperate act of a young disillusioned lover who has abandoned her hopes for complete passionate love and is seeking a father protector. A stage along her way. On the other hand, the solution she chooses and seems to believe in, even after all the experiences she has had, suggests an endearingly trustful nature that includes an innate sense of whom to trust, which has not changed much and perhaps never will.

Bowen also reflects Portia's double nature in the structure of the text. The novel's chapter headings ("The World," "The Flesh," and "The Devil"), are reminiscent of medieval allegory, and also, less clearly, of Botticelli's allegorical titles. The juxtaposition of those allegorical headings with the novel's contents, which foregrounds the emotional and stylistic atmosphere of the 1930's, achieves a combination of eternity and mutability. A moral tale for all time merges with a bildungsroman set clearly in the mid-twentieth century. On a more specific narratological level, this subtext creates a kind of narrative prolepsis, or foreshadowing: for Portia to become a well-known Botticelli, even if momentarily within the text, prefigures her crystallization as a person, an event the novel teasingly ends before portraying. And ironically enough, it is Eddie who completes the portrait.

Thus even as Portia plays Primavera, and nature's mutability, she also partially subverts both its temporal and eternal messages: its sense of inevitable natural progression as well as its portrayal of woman as especially subject to that progression. Portia's di- 
ary is not really subject to seasons; it asserts the value of emotional truth even though the person who upholds that truth is subject to seasonal change. As Phyllis Lassner points out, Bowen charts Portia's struggle to gain control over her life, and "to wrest her story from a pre-determined pattern"' $(1990,119)$. She cites the narrator's statement that "the strongest compulsions we feel throughout life are no more than compulsions to repeat a pattern: the pattern is not of our own device" (169). Portia's diary, of course, is a primary factor in Portia's progress to control her destiny.

A pattern "not of our own device," but one to which we must submit nonetheless is the inevitable march of time as evidenced by the inexorable progress of the seasons. Even though Portia struggles against some patterns, like the social ones into which her precarious existence forces her, and also against the inevitable pain that her springtime with its growth subjects her to, Bowen also suggests that an immersion in this natural tide is preferable to an exclusion from it. Anna's life is an artificial one of brittleness and social play while Portia's is connected, albeit painfully, to the natural world of change and growth. Although near the end of the novel Anna shows some signs of thawing, for the most part she remains unseasonably frozen in midwinter ice while Portia as Primavera is attuned to the coming of spring. If, as Lassner maintains, it is true that in this novel Bowen "deactivates" her earlier "reliance on houses as strategies for self-preservation and demystifies them as determining [patriarchal] structures" in favor of writing that creates meaningful personal relationships, then in painting Portia as Primavera, Bowen makes nature her ally as she writes her way out of stifling interiors.

Not only does the connection with Botticelli's Primavera alert us to Bowen's themes of eternity and mutability, and underscore the emotional inadequacy of Portia's social world, but the critique of the gaze that the visual subtext embodies also underlines the more obvious issues of gazing that drive the plot of the novel. That plot revolves around Anna's discovery that Portia is keeping a diary about their household, and Portia's discovery of that discovery. (The play with mirrors in this novel is more than a passing stage.)

Anna is the center of Portia's anguish, the primary object of her largely pre-oedipal gaze, but in the triangle of Portia, Anna, and Eddie, she suffers oedipal pangs as well. Another doubling of her role, and appropriate, for although Portia is actually sixteen, the age ripe for restagings of the oedipal phase, she looks "about ten," in the words of an admirer, who asks her if anyone hasn't ever told her she looked like a "sweet little kid" (168). Indeed, she appears very childlike: her belt slips down her slim, childish hips, she sits sipping her tea on a low stool, and plays at giving bears a tea party in her room. Portia's gaze, however, in contrast to her demeanor, is advanced for her years, an indication of Bowen's staging of female narrative empowerment through her. The gaze is ruthless and curious, the demeanor that of the sweet little kid. Portia's gaze thus belongs to what Elizabeth Bronfen terms the Freudian "masculine scopophilia," which consists of gazing at an object foreign to oneself, in contrast to the "feminine exhibitionism," in which one is the object of another's gaze $(1996,82)$. Bowen reverses the genders of gazer and object. If we look again, from this perspective, at the scene in the 
woods, we can now see that if Portia is Primavera, she is an avowedly awkward Primavera (in her "beastly reefer coat") not comfortable in the role of the beheld; and Eddie's suggestion that she transfer her violets to his own coat confirms this reversal of roles.

If, as Laura Mulvey has formulated it, "the male unconscious has two avenues of escape from castration anxiety," voyeurism or fetishization, the latter "turning the represented figure itself into a fetish so that it becomes reassuring rather than dangerous," then Bowen has Portia engage in both these strategies $(1984,368)$. In lieu of the oedipal primal scene, Bowen sketches an alternative voyeuristic moment, preoedipal in nature, when Portia takes Major Brutt's flowers to Anna who is about to bathe: "Anna opened the door, showing a strip of herself and letting out a cloud of scented steam." After inquiring about the flowers, Anna says, "Well, Portia, let's have a talk later," and shuts the door (237). This moment does not recreate a particular painting, but rather suggests the possibility of an incomplete modern nude that contrasts with the polished and delicately veiled Primavera. Because it is possible that Portia does see Anna naked, this glimpse almost provides a visual analogue for Portia's unmasking of Anna in her diary, except that she is more tentative here than there, and she only sees a slice.

In this scene Portia may almost achieve the Freudian nachtreiglichkeit, that glimpse of a seminal scene in the past behind a present one. However, this is no duplication of the moments of intimacy and female warmth Portia shared with her mother in the shabby but happily cozy hotel rooms they inhabited, for she is excluded from the warmth and intimacy of Anna's bath, and even if she weren't, that maternal warmth is only simulated by the artificially created steam in Anna's bathroom. Botticelli is relevant again here: appropriately for this novel in which the central conflict is between women, women are the central figures in the Primavera. Botticelli's weaving together of the women in the painting visually undergirds Bowen's fictional design, which shows Anna and Portia struggling to begin to articulate the possibility of a relationship. If, as Lassner asserts, this process alters the domestic novel, Bowen may have called for the help of an acknowledged master, as she innovates, and one whose neoplatonic perspective reaches beyond the human.

On her seaside vacation, Portia tries Freud's other alternative to avoiding emotional castration, fetishization, by fixating on Mrs. Heccomb's drawing of Anna as a child, a sketch whose "tender incompetence" makes Anna with her hair tied in silken bows and holding a kitten look "spiritual." Portia first wonders about the child Anna's inner life, and later, when Portia returns to the sketch after an upset about Eddie, Bowen virtually shows her fetishizing. She "looked hard" at the portrait, but "did not know what she looked for in the pastel-confirmation that the most unlikely people suffer, or that everybody who suffers is the same age?" Portia continues to look at this picture, for it "continued to enter her waking mind," just as it had entered her dreams when she arrived. And as if to signal its value as a fetish, Bowen explains Portia's fixation on the sketch by saying that "what help she did not find in the picture she found in its oak frame and the mantelpiece underneath. After inside upheavals, it is important to fix on imperturbable things" (206). Back at home, she attempts to enliven this same fetish by 
mentioning it to Anna, but gets nowhere. Neither voyeurism not fetishization, but the possibility of a living relationship, are what Portia will continue to seek.

No one is exactly happy under anyone else's eyes in this novel, but by the end, Portia's verbal gaze does seem to have had a salutary effect on its objects. At the beginning, when Anna has only just discovered Portia's diary, she appears to resist the insights about her that this portrait reveals: "That diary could not be worse than it is. That is to say, it couldn't be worse for me." She considers it "completely distorted and distorting. As I read I thought, either this girl or I are mad. And I don't think I am." And she claims that Portia "was so odd about me" (10-11).

At the end, however, Anna seems to have recognized her own image in Portia's portrait of her, and that self-recognition has increased her emotional intelligence. Anna intuits correctly that Portia (who has run away) is waiting to come home "to see whether we do the right thing," admitting that "I don't say it [the diary] has changed the course of my life, but it's given me a rather more disagreeable feeling about being alive -or, at least, about being me," and finally making quite a long speech empathizing with Portia's judgment of them all when Thomas asks her how she'd feel if she were Portia: "If I were Portia? Contempt for the pack of us, who muddled our own lives then stopped me from living mine. Boredom, oh, such boredom .... Wish that someone outside would blow a whistle and make the whole thing stop." The extent of her empathy prompts Thomas to observe that "this is all quite new," and to ask her "how much is the diary, how much is you?" (312). In that moment, when Anna sees herself through Portia's eyes, the voyeuse and the object of her gaze merge, providing Anna with a moment of unusual self-awareness, but it is only a moment, for directly afterwards Anna separates herself, declaring that Portia and she "are hardly the same sex." The psychological acuity that achieves the coincidence of gazer and object is necessarily a rare event. But that moment, together with the many other scrutinies of gazing that the novel presents, reveals Bowen's sensitivity -avant la lettre- to the subtle dynamics of gazing that recent critiques have been exploring.

In these studies of gazers and their objects, then, we can see that, writing in a proto-, rather than an overtly feminist mode, Bowen establishes female narrative credibility in a partially male register. Thus, instead of dismantling the ocularcentric gaze articulated through several centuries of bourgeois patriarchal gazing entirely, Bowen both presents a virtually hidden critique of it -in the Botticelli subtext- and, more overtly, adopts that tradition for Portia to use. The penetrating nature of Portia's gaze means that she appropriates the gaze, becoming a powerful voyeuse, the proverbial female lack supplanted by her diary's pen. Once empowered, Portia as Primavera and Portia as voyeuse balance each other. In embodying both male and female traditions of gazing, being by turns both object and subject, this ocular balancing act positions Portia, like Bowen, as a strongly emergent but not a rebellious female voice, and, like Bowen, as a sexually androgynous one as well. That fruitful combination is reinforced if we recall the neoplatonic interpretation of Botticelli's painting. Inasmuch as it is her diary that provides the impetus for a strong moral critique of Anna's emotional wasteland, Portia provides both the agency that leads toward a higher realm, and which Zephyr's breath 
represents in the painting, and the embodiment of its effects in the figure of Primavera herself, again combining the traditional roles of male agent and female object. ${ }^{9}$ And the higher realm to which her emergence as a literate Primavera points, is the realm not only of refined spiritual connection to the cosmos, but of fully realized relationships.

Finally, to return once again to the temporal theme with which we began, Bowen's visual subtext locates her and her readers between Renaissance houses and modern streets. It endows her social satire and psychological portraiture with latent layers of cultural memory, the kind of memory that Bowen values as a stay against the emptional brittleness and material chaos of modern life. ${ }^{10}$

\section{Notes}

'Letter to A.E. Coppard from August 31, c. 1937 (No year given on the letter, but it is near to the publication of The House in Paris). The letter is in the Elizabeth Bowen collection at the Humanities Research Center at the University of Texas at Austin. Bowen's sensitivity to painting, and the consequent possibility that she would have been familiar with a masterpiece such as Botticelli's is suggested by her early desire to become an artist, an ambition which she abandoned after two terms at the London County Council School of Art. According to Bowen, "it seems to me that often when I write I am trying to make words do the work of line and colour. I have the painter's sensitivity to light. Much (and perhaps the best) of my writing is verbal painting." An autobiographical note, circa 1949 , cited (without a more specific reference) by Victoria Glendinning $(1979,43)$.

2 Bowen gives additional evidence of her familiarity with the Italian Renaissance and her sense of its contrast with modern life in a letter to Lady Ottoline Morrell: "I do wish I were with you this afternoon, instead of showing photographs of Renaissance Italy in a cold hall to little boys who will not know what it's about - Do you wish, ever, you had lived then? I always feel certain that time and place is your home." Letter of December 1, probably 1932, in the Elizabeth Bowen collection at the Humanities Research Center at the University of Texas at Austin.

${ }^{3}$ This letter was written before the publication of The Death of the Heart; bearing the date of October 14 but not the year, it is in a folder with letters from 1927-1938 in the Bowen collection at the Humanities Research Center at the University of Texas at Austin.

${ }^{4}$ For an investigation of another Renaissance -Shakespearean- subtext in Bowen's novel, see Ann Ashworth's article (1987).

${ }^{5}$ The Botticelli subtext with its attendant neoplatonism alerts us to a latent dimenion of Bowen's work that moves beyond the purely personal, domestic, and social, to suggest a spiritual realm beyond them, but only to suggest, not to develop it, and one which is very much tied to earthly people and places. Evidence that Bowen was sensitive to such a realm is scarce. One shred exists in a 1946 letter to Charles Ritchie:

I have been very conscious of religion these last months here in this country. To be a Roman Catholic myself would be as unthinkable as ever. But I do see the efficacy and 
all-embracingness and sublimity of Catholicism in its effects on all the people's beings and lives around here. It seems to me to make them hardboiled and spiritual at the same time. On Saints' Days, especially All Saints' Day yesterday, which they call 'the day of the dead,' one feels a sort of influence in the air like the flame of a candle burning. (Glendinning 1979, 267)

${ }^{6}$ For a discussion of this aspect of Primavera, see Liana De Girolani Cheney's book (1993, 98-99).

${ }^{7}$ Umberto Baldini associates Foscolo's poem with Botticelli's painting in his essay on the allegorical significance of the painting (1986, 101).

${ }^{8}$ That Proust's use of Botticelli in "Swann in Love" might have influenced Bowen is possible, since she was an admiring reader of Proust. She wrote an essay on "The Art of Bergotte," pursuing the question of a possible real life model for Proust's character in A la recherche. According to Glendinning, "Maupassant never meant as much to her as Flaubert, or as Proust" $(1979,132)$.

${ }^{9}$ This interplay of sexual personae reflects the notion that, as Renee Hoogland has suggested, Bowen did "not subscribe to a notion of her sex as helplessly victimized by an oppressively patriarchal culture," and also that "her position toward (the exertion of) discursive power in relation to gender" is a complex one $(1994,22)$.

${ }^{10}$ In an article on Bowen's conservative values, John Coates associates the swans at the beginning of the novel swimming "in slow indignation" with Yeats's elegiac swans in "Coole Park and Ballylee 1931," a virtually contemporaneous poem that mourns the passing of the old Irish order. According to Coates, we must take the death of the heart not in its purely individual dimension: "rather, the novel carefully connects the emotional failure, and the particular act of cruelty and treachery which exemplify it, to the whole texture of the society displayed" $(1985,249)$. The conservative values Bowen implicitly advocates do not seem to extend to gender roles, however.

\section{Works cited}

Ashworth, Ann. 1987."'But Why Was She Called Portia?': Judgment and Feeling in Bowen's The Death of the Heart." Critique: Studies in Contemporary Fiction 28, iii: 159-66.

Bal, Mieke. 1997. The Mottled Screen: Reading Proust Visually. Trans. Anna-Louise Milne. Stanford: Stanford University Press.

Baldini, Umberto. 1986. Primavera: The Restoration of Botticelli's Masterpiece. New York: Harry Abrams.

Bowen, Elizabeth. 1942. Bowen's Court. New York: Knopf. 1962. The Death of the Heart. London: Penguin.

Bronfen, Elizabeth. 1996. "Killing Gazes, Killing in the Gaze: On Michael Powell's Peeping Tom." Gaze and Voice as Love Objects. Eds. Renata Salecl and Slavoj Zizek. Durham: Duke University Press. 59-89.

Coates, John. 1985. "In Praise of Civility: Conservative Values in Elizabeth Bowen's The Death of the Heart." Renascence: Essays on Value in Literature 37, iv: 248-65. 
De Girolani Cheney, Liana. 1993. Botticelli is Neoplatonic Images. Potomac, Maryland: Scripta Humanistica.

Foucault, Michel. 1973. The Order of Things. New York: Random House.

Glendinning, Victoria. 1979. Elizabeth Bowen. New York: Avon.

Hoogland, Renee. 1994. Elizabeth Bowen: A Reputation in Writing. New York: New York University Press.

Hartt, Frederick. 1987. History of Italian Renaissance Art. London: Thames and Hudson.

Lassner, Phyllis. 1990. Elizabeth Bowen. Savage, Maryland: Barnes and Noble.

Mulvey, Laura. 1984. "Visual Pleasure and Narrative Cinema." Art After Modernism: Rethinking Representation. Ed. Brian Wallace. New York: The Museum of Contemporary Art. 361-373.

\section{Illustrations}

Figure 1. Sandro Botticelli, Primavera c. 1482. Panel, $6^{\prime} 8^{\prime \prime}$. Uffizi Gallery Florence. In Hartt (1987, 310)

Figure 2. Primavera (detail) 